\title{
MEDIALNE WYKORZYSTYWANIE IGRZYSK OLIMPIJSKICH W BUDOWANIU TOŻSAMOŚCI NARODOWEJ WĘGRÓW
}

Od 2010 r. rząd węgierski ogromną wagę przywiązuje do rozwoju sportu, szczególnie piłki nożnej i promocji ruchu olimpijskiego. Widać to na każdym kroku, zarówno na przykładzie ustawy z 2011 r. nakazującej wprowadzenie w szkolnictwie podstawowym codziennych lekcji wychowania fizycznego, jak też na ogromnych wydatkach budżetowych na budowę bądź rekonstrukcję różnych obiektów sportowych, w tym stadionów. Także w rodzinnej wsi premiera został wybudowany stadion - Akademia Piłki Nożnej im. Ferenca Puskása. Arena Pancho, ${ }^{1}$ mieszcząca 3.500 osób, podczas gdy liczba mieszkańców miejscowości Felcsút ${ }^{2}$ wynosi zaledwie 1.800 osób.

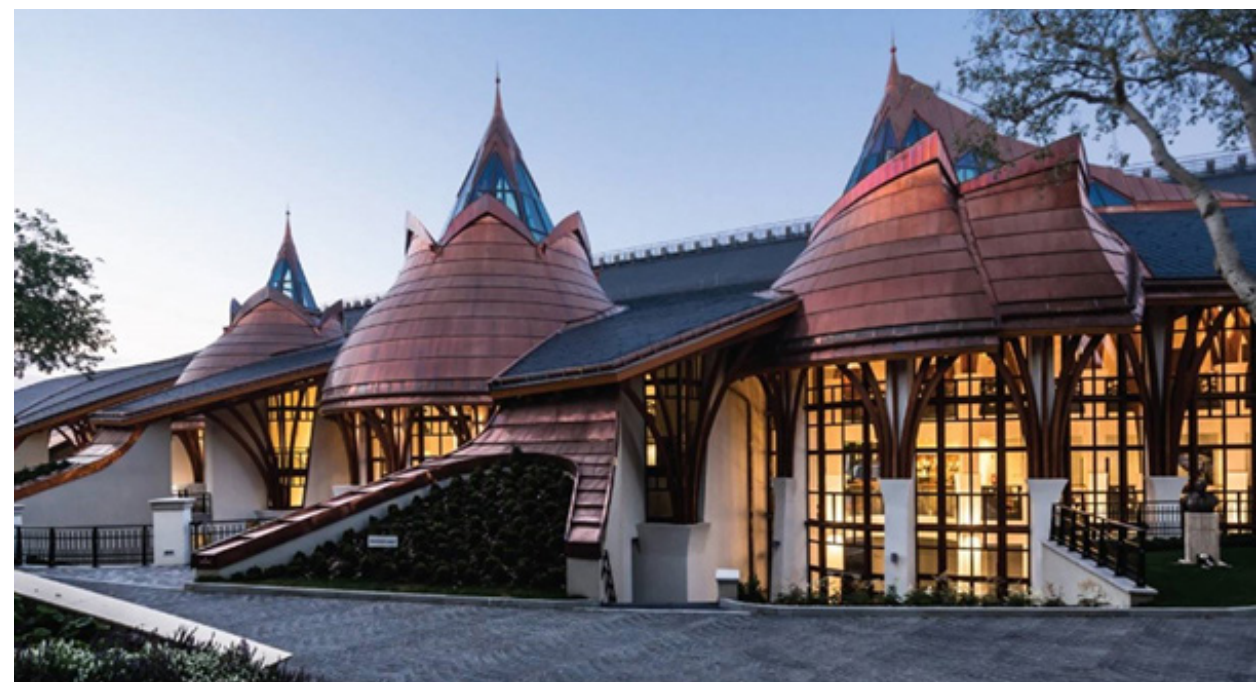

* DR CSC LÁszló KÁlmÁn NAgY, PROF. UJ - Zakład Filologii Węgierskiej w Instytucie Językoznawstwa Uniwersytetu Jagiellońskiego, e-mail: nagy.laszlo@interia.eu.

${ }^{1}$ Zob.: https://hu.wikipedia.org/wiki/Pancho_Ar\%C3\%A9na Link dostępny 4 marca 2017 r. Pancho - to odmiana imienia wielkiego piłkarza Ferenca Puskása w języku hiszpańskim.

${ }^{2}$ Felcsút obecnie jest najbogatszą miejscowością na Węgrzech. Średni dochód na mieszkańca wynosi więcej niż w ekskluzywnej II dzielnicy Budapesztu (ponad 170 tys. forintów na osobę). Pod 


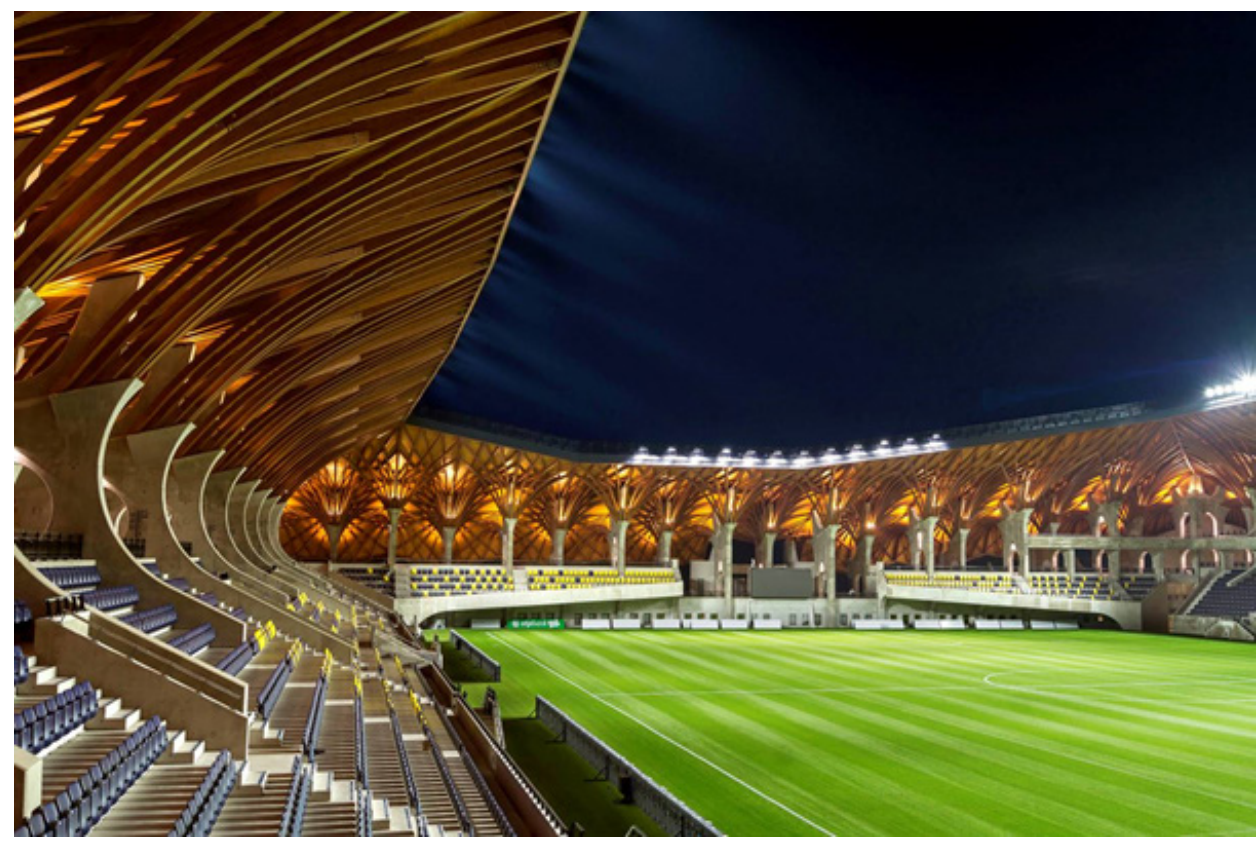

Ilustracja $1,2^{3}$. Arena Pancho 01-02, Arena Pancho i dom premiera w miejscowości Felcsút.

Akademie piłki nożnej powstały także w innych miastach, np. w Debreczynie (w 2011 roku).

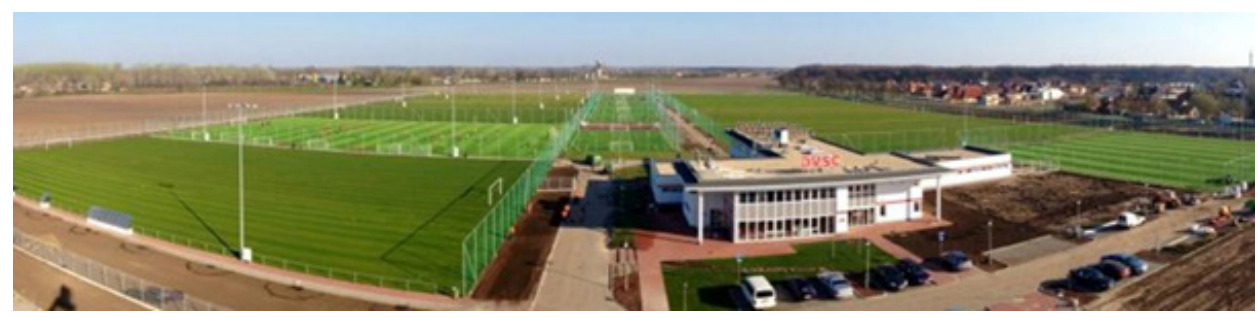

Ilustracja 3. Otwarcie Akademii Piłki Nożnej w Debreczynie; Akademia z lotu ptaka.

Paralelnie z promocją sportu rząd z niesłabnącym zaangażowaniem dąży do rozbudzenia w społeczeństwie węgierskim uczuć patriotycznych i nacjonalistycznych, w którym to procesie ważne miejsce zajmuje mitologizacja sukcesów węgierskich sportowców w przeszłości. Retoryka łączenia sukcesów z motywem służby ojczyźnie

względem zamożności mieszkańców w 2008 roku Felcsút zajmował dopiero 35. miejsce w kraju. Patrz: link powyżej. Ze środków unijnych została tam wybudowana także kolejka wąskotorowa o długości 3,5 km, prowadząca od Arboretum do Stadionu, praktycznie do domu premiera.

3 Wszystkie ilustracje do tego artykułu dostępne są na stronie internetowej http://members.upc. hu/nagylk/ilustracje.htm 
odwołuje się do rosnącej dumy narodowej i wzmocnienia poczucia wspólnoty Węgrów żyjących w krajach ościennych. Ma ona służyć także uzasadnieniu ogromnych inwestycji przeznaczonych na finansowanie sportu wyczynowego. Podczas ostatniej olimpiady za ponad półtora miliarda forintów wybudowano w Rio de Janeiro „Dom Węgierski”, który promował Budapeszt ubiegający się o prawo do organizowania Igrzysk w 2024 roku. ${ }^{4} \mathrm{~W}$ przemówieniu wygłoszonym w tym obiekcie premier Orbán podkreślił symboliczne znaczenie obchodów święta narodowego (św. Stefana) na innym kontynencie, właśnie w Rio. Premier podkreślił ponadto, iż podczas Olimpiady, która w 2024 roku ma szansę odbyć się w Budapeszcie, cała stolica powinna funkcjonować jak ogromny park olimpijski, a 90\% mieszkańców kraju w ciągu 90 minut mogłoby dotrzeć do miejsc wydarzeń sportowych. (Nie wiadomo, na czym są oparte te konkretne liczby). Orbán nawiązał także do przeszłości historycznej narodu węgierskiego. Nadmienił, że Węgrzy w całym XX wieku musieli szukać swej tożsamości narodowej i walczyć o przetrwanie. Wśród wszystkich trudności jedynie sukcesy sportowe dawały ludziom nadzieję i otuchę, jedynie na boiskach sportowych mogli ujrzeć tryumfującą flagę narodową.

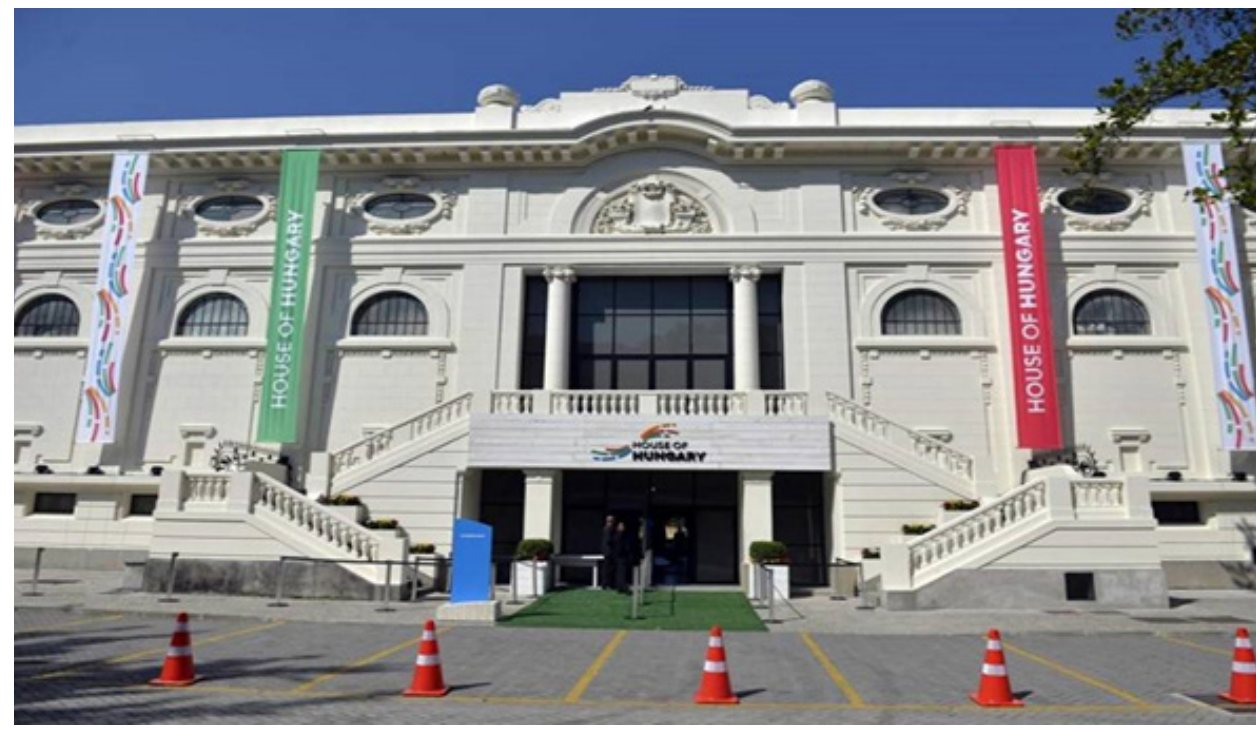

Ilustracja 4. Dom Węgierski w Rio.

Słowa Orbána w sposób zawoalowany nawiązywały do ogromnego sukcesu z 1953 r., kiedy „Złota Jedenastka” brawurowo pokonała reprezentację Anglii, i to na stadionie w Wembley. Do tego historycznego zwycięstwa nieco później jeszcze powrócimy. W pierwszej połowie pięćdziesiątych lat rzeczywiście był to ogromny

${ }^{4}$ Por.: http://24.hu/belfold/2016/08/20/orban-rioban-hazalt-a-budapesti-olimpiaval/ Link dostępny 10 marca $2017 \mathrm{r}$. 
sukces nie tylko w dziedzinie sportu, lecz również w polityce. Należało odbudować nadszarpnięty podczas II wojny światowej i w pierwszych latach stalinizmu wizerunek kraju.

Słowa premiera wygłoszone w Rio oraz cała retoryka i logistyka związana z przygotowaniami za czasów obecnego rządu do Igrzysk w Londynie (2012) i Rio (2016) wyznaczają pewną cezurę w historii węgierskiego sportu. Ruch olimpijski został mocniej niż kiedykolwiek w okresie powojennym upolityczniony. Promocja sportu wyczynowego ponad możliwości finansowe kraju unaocznia obecność i celowe podtrzymywanie w świadomości zbiorowej Węgrów wciąż żywych kompleksów narodowych, w tym kompleksu niższości i kompleksu małego kraju - połączonych jednocześnie z manią wielkości i chęcią odbudowy zmitologizowanego wizerunku Węgier przedtrianońskich.

Mając na uwadze tytuł tego artykułu, zamierzałem zająć się problematyką medialnego wykorzystywania dla wzmocnienia uczuć patriotycznych tylko dwóch ostatnich Letnich Igrzysk Olimpijskich. Prasa drukowana i internetowa, transmitowane przez telewizję programy sportowe, przemówienia sportowców i polityków oraz szeroko zakrojona kampania reklamowa - wszystko to dostarcza sporo materiałów do badania tej kwestii. Jednak podczas pracy nad artykułem niby niespodziewanie rozgorzał na Węgrzech ostry spór wokół kandydatury kraju naddunajskiego na organizatora letnich Igrzysk Olimpijskich w 2024 roku. Jak już wspomniano, o poparcie dla tej kandydatury gorąco apelował premier właśnie w „Domu Węgierskim" w Rio - i wówczas nie pojawiały się jeszcze polemiczne opinie stawające pod znakiem zapytania sens forsowanej promocji ruchu olimpijskiego.

Podczas prowadzenia nowego sporu wyłonił się nowy ruch obywatelski o nazwie „Momentum” (czyli w języku polskim Moment). Liderzy nowego ruchu zaatakowali przede wszystkim sprawę kandydatury Węgier do zorganizowania przez Budapeszt Igrzysk. Ruch błyskawicznie, w ciągu kilku tygodni przekształcił się w partię polityczną. Powstanie nowej partii dobitnie świadczy o głębokim podziale politycznym społeczeństwa nie tylko odnośnie olimpiady. Potwierdza niezadowolenie sporej części Węgrów z obecnie istniejących partii i sposobu rządzenia krajem. A propos kandydatury Węgier zaczęto otwarcie mówić o tym, że przedsiębiorstwa mogą przeznaczyć część podatku dochodowego na dofinansowanie klubów i obiektów sportowych, a te pieniądze przez to niby „tracą charakter pieniędzy publicznych”. A potem te dość pokaźne kwoty wykorzystywane są na dowolne cele i nie trzeba $\mathrm{z}$ nich się rozliczyć. Zaczęto też mówić o aktualnych problemach finansowania na Węgrzech oświaty i służby zdrowia. Bieżąca sytuacja skłoniła mnie więc do tego, bym swoją uwagę skupił przede wszystkim na medialnym wydźwięku burzliwych sporów z ostatnich miesięcy. Bezpośrednio związane były one z kandydaturą Węgier do zorganizowania Olimpiady 2024 r., ale dyskusja daleko wykraczała poza temat sportu i ruchu olimpijskiego.

Co się tyczy wcześniejszego, „ogólnonarodowego” poparcia dla zorganizowania Igrzysk w Budapeszcie, należy przypomnieć, że Węgierski Komitet Olimpijski 
w głosowaniu z 6 lutego 2015 r. podjął decyzję (12 głosów „za”, 1 ,pprzeciw”) w sprawie postawienia wniosku o rozpatrzenie możliwości zorganizowania przez Budapeszt Letnich Igrzysk Olimpijskich i Paraolimpijskich w 2024 r. Nie sposób przemilczeć faktu, że komitet ten w społeczeństwie węgierskim od początku cieszy się ogromnym autorytetem. Jest bowiem drugą najstarszą po Węgierskim Czerwonym Krzyżu ${ }^{5}$ organizacją społeczną, która aktywnie działa także dzisiaj. Założony został w 1895 r., a jednym z jego przewodniczących był Gusztáv Sebes (1906-1986), którego sylwetka była przedstawiana w trakcie poprzedniej konferencji olimpijskiej w 2016 r. Nazwisko Sebesa nawet po sześćdziesięciu latach znane jest na całym świecie dzięki temu, że był wybitnym piłkarzem, trenerem i kapitanem związkowym ,Złotej Jedenastki”. ${ }^{6}$ Wnioski stawiane przez Węgierski Komitet Olimpijski zazwyczaj są akceptowane przez parlament, a sformułowane przez jego kierownictwo opinie mogą liczyć na pełne zrozumienie społeczeństwa. W 2015 r. nastąpiła jednak jakaś zmiana, która zainicjowała odwrót od dotychczasowego kursu.

6 lipca 2015 r. parlament węgierski podjął decyzję o poparciu kandydatury Węgier w ubieganiu się o zorganizowanie Igrzysk w 2024 r. Wprawdzie wszystkie parlamentarne partie opozycyjne, czyli: Węgierska Partia Socjalistyczna (MSZP), Koalicja Demokratyczna $(D K)$, Razem (Együtt) Dialog na rzecz Węgier (PM) oraz Polityka Może Być Inna $(L M P)$ były przeciw, to i tak decyzja została podjęta, ponieważ Fidesz ma w parlamencie większość 2/3 głosów. Dodatkowo poparł ją skrajnie prawicowy Jobbik ${ }^{7}$. Rząd jak najwcześniej chciał doprowadzić tę ważną dla niego sprawę do szczęśliwego finału. Dlatego też już następnego dnia, czyli 7 lipca 2015 r., zostało przekazane Międzynarodowemu Komitetowi Olimpijskiemu pismo intencyjne dotyczące kandydatury Węgier do Letnich Igrzysk Olimpijskich w 2024 r. Na początku grudnia tegoż roku odrzucono wniosek socjalistów w sprawie rozpisania referendum o zorganizowanie przez Budapeszt Igrzysk Olimpijskich, o czym donosiła cała prasa. Przykładowo na łamach gazety „Nemzeti Sport” (Sport Narodowy) 2 grudnia ukazał się artykuł pt. Budapest vezetői nem akarnak népszavazást (Przywódcy Budapesztu nie chcą referendum).

Koszty zorganizowania igrzysk olimpijskich na początku szacowano na 770 miliardów forintów (11 miliardów zł), ale wedle ekspertów łączne koszty mogłyby osiągnąć kwotę 2.700 miliardów, co praktyczne oznacza, że każdy obywatel kraju statystycznie (łącznie z noworodkami) musiałby dołożyć do tego interesu grubo ponad ćwierć miliona forintów, co w polskiej walucie stanowi równowartość około czterech tysięcy zł.

${ }^{5}$ Węgierski Czerwony Krzyż założony został 16 maja 1881 r. Zob. i por.: https://hu.wikipedia. org/ wiki/Magyar_V\%C3\%B6r\%C3\%B6skereszt Lik dostępny 1 marca 2017 r.

${ }^{6}$ Sebes pełnił funkcję przewodniczącego Węgierskiego Komitetu Olimpijskiego w latach 1948-1951 razem w Zsigmondem Ábraim (1893-1984), który również był piłkarzem.

${ }^{7}$ Nazwa tej partii w języku węgierskim stanowi homonim. Jednocześnie oznacza „lepszy”, „prawy”, ,prawostronny”. 
Najsilniejszym argumentem przeciwników kandydatury Węgier w zorganizowaniu Letnich Igrzysk były więc obawy przed niekontrolowanym wzrostem kosztów, w tym nie tylko uzasadnionych. Część społeczeństwa ma świadomość szerzącej się korupcji na Węgrzech i jest przekonana o tym, że sterowane przez rząd zamówienia publiczne dałyby możliwość do defraudacji przez „wybranych” kolejnych miliardów forintów. Głosy polityków opozycji i niektórych organizacji obywatelskich stały się coraz bardziej zdecydowane. Zaczęto podważać nie tylko sens samego przedsięwzięcia, lecz także sens całej polityki rządu związanej z promocją sportu wyczynowego.

Taka sytuacja mogła zaistnieć właśnie dlatego, że w ostatnich kilku latach Węgry rzeczywiście słyną z rosnącej korupcji i skandali związanych z niewłaściwym wykorzystaniem funduszy unijnych. Węgry w całej Unii Europejskiej należą do krajów najbardziej skorumpowanych. Większa niż na Węgrzech korupcja istnieje ponoć tylko w Bułgarii i Rumunii. O ile jednak korupcja w Rumunii z roku na rok sukcesywnie maleje, o tyle na Węgrzech ma tendencję wciąż rosnącą. Wedle OLAF, czyli Europejskiego Urzędu ds. Zwalczania Nadużyć Finansowych w roku ubiegłym zdefraudowane zostały na Węgrzech nawet unijne środki przeznaczone na walkę z korupcją (w wysokości ponad miliarda forintów) ${ }^{8}$

Jak pokazują dane, do chwili wystąpienia ruchu „Momentum” na zorganizowanie Igrzysk wydano już dwadzieścia miliardów forintów, a łącznie z zakupem działek przeznaczonych na budowę obiektów sportowych kolejne siedemnaście miliardów. ${ }^{9}$ Nie są to jednak dane do końca jawne (aczkolwiek powinny być), zostały one z trudem uzyskane przez pewnych polityków. Na przykład ani w przyjętym przez parlament budżecie zeszłego roku, ani w obecnym nie występuje pozycja dotycząca organizacji olimpiady. Została ona przez rząd później dopisana.

$\mathrm{Na}$ tle rozbudzonego ,apetytu” społeczeństwa na „prawdę o olimpiadzie” ruch „Momentum” do 18 lutego br. zebrało w Budapeszcie ponad 266 tys. ważnych głosów (wobec wymaganych 138 tys.) w sprawie rozpisania w stolicy referendum dotyczącego wycofania kandydatury. Do czasu referendum miała być zawieszona realizacja wcześniej zawartych umów, a kolejne przetargi miały być nierozpisywane. Akcja zbierania podpisów przeprowadzona została pod trafną nazwą „NOlimpia”. Znamienne, że prawo do składania podpisów mieli tylko mieszkańcy samego Budapesztu. Wniosek w sprawie uczestniczenia w konkursie formalnie zgłoszony został bowiem nie przez rząd, tylko przez sejmik miasta stołecznego z prezydentem stolicy na czele.

${ }^{8}$ Zob. i por. m.in.: https://444.hu/2016/01/24/elloptak-a-korrupcio-elleni-harcra-kapott-penzeket. http://hvg.hu/gazdasag/201604_nyomozas_unios_penzek_miatt_csalas_a_csucso, http://index.hu/ belfold/2016/01/24/a_korrupcio_elleni_penzeket_lophattak_el_magyar_kozbeszerzesi_ellenorok/. Linki dostępne 01 marca $2017 \mathrm{r}$.

9 Zob.: http://k-monitor.hu/adatbazis/cimkek/budapest-2024 -olimpiai-palyazat? gclid=CNzXw_T50N ICFSEW0wodqtIGdg. http://magyarnarancs.hu/belpol/mar-37-milliardnal-jarnak-azolimpiai-palyazat-koltsegei-102406 Linki dostępne 05 marca 2017 r. 
Aktywiści ruchu „Momentum” podczas zbierania podpisów nieraz bywali znieważani przez różne osoby prywatne. Zdarzały się także prowokacje w formie niepodawania właściwych danych przez składające podpisy osoby, by zmniejszyć liczbę głosów ważnych.

Ilustracja: Zbieranie przez ruchu obywatelski „Momentum” podpisów w sprawie rozpisania referendum $01-04$

Wraz ze przybywaniem zbieranych podpisów diametralnie zmieniała się opinia Węgrów na temat Olimpiady. Po złożeniu podpisów, żeby nie dopuścić do referendum, które mogło stać się wielką porażką rządu, 22 lutego na spotkaniu premiera Viktora Orbána z prezydentem Budapesztu i z przedstawicielami Węgierskiego Komitetu Olimpijskiego podjęto wspólną decyzję o wycofaniu kandydatury. Oficjalne uzasadnienie decyzji przypominało nowomowę z lat realnego socjalizmu. Nawiązano w nim do rzekomo celowego rozbicia przez opozycję jedności narodu. Sprawie Olimpiady nadano cech sprawy narodowej, a naród w rozumieniu rządu to partia rządząca. Wedle tłumaczenia premiera opozycja jawnie zaatakowała istniejący od 2010 r. System Współpracy Narodowej, czyli NER (więc po polsku SWN). ${ }^{10}$ Dalej idąc tropem tej logiki, została zdradzona cała, niesprecyzowana bliżej „sprawa narodowa”, za co odpowiedzialność ponosi tylko i wyłącznie opozycja. Już podczas zbierania podpisów m.in. prezydent Budapesztu jawnie nazywał podpisujących zdrajcami ojczyzny, w ten sposób apelując do uczuć patriotycznych. Pod tym względem widać powrót do retoryki nawet nie okresu miękkiej dyktatury, tylko początku lat pięćdziesiątych, kiedy przez władzę komunistyczną lansowany był slogan ,kto nie jest z nami, jest przeciwko nam”. Dopiero po powstaniu węgierskim 1956 r., w okresie Kádára i „naszej -tj. węgierskiej małej stabilizacji” slogan ten zamieniono na „kto nie jest przeciwko nam, jest z nami”. Słowa prezydenta stolicy, który w pełni utożsamia się z rządem i Fideszem, najwyraźniej odwoływały się jednak do wersji stalinowskiej - kto nie jest z nami (tj. z rządem), jest zdrajcą i wrogiem.

Ważne, że ruch Momentum przekształcił się w partię polityczną dopiero po złożeniu podpisów. Współpraca partii opozycyjnych z ruchem podczas zbierania głosów kształtowała się różnie, choć większość partii generalnie poparła tę inicjatywę. Nowa partia w chwili obecnej zdecydowanie odrzuca określanie jej

10 Sama nazwa SWN (NER) po węgiersku tak samo mało mówi, jak po polsku. Jest to nazwa nowego sposobu zarządzania krajem od chwili wygrania przez Fidesz wyborów w 2010 r. Premier nazwał SWN nowym „ustrojem”, nową ,umową społeczną”. Nowy ustrój zainicjowany został wygłoszeniem w Parlamencie 14 czerwca 2010 r. Deklaracji Współpracy Narodowej. Jej wiodącym hasłem było „Niech będzie pokój, wolność i porozumienie”. Tekst deklaracji obligatoryjnie umieszczono do wglądu w każdej instytucji administracji państwowej. Więcej o NER: https://hu.wikipedia. org/wiki/Nemzeti_Egy\%C3\%BCttm\%C5\%B1k\%C3\%B6d\%C3\%A9s_Rendszere. Link dostępny 05 marca 2017 r. Do momentu złożenia do druku tego tekstu zaistniała już na Węgrzech trawestowana wersja nazwy tego systemu: NKR - Nemzeti Korrupció Rendszere, czyli System Korupcji Narodowej. 
w dotychczasowych przeciwstawnych kategoriach prawica - lewica. Stara się zachowywać jednakowy dystans zarówno do socjalistów, jak i Fideszu, do skrajnej prawicy i do małych partii demokratycznych. Zamierza samodzielnie startować w wyborach parlamentarnych w 2018 roku. Nowa partia budzi sporo sympatii wśród Węgrów. W jej działaniach i środkach, którymi dąży do celu, widać jednak typowe, historycznie ukształtowane cechy narodowe Madziarów, niezwiązane z żadnym konkretnym ustrojem lub epoką. Jest to m.in. skrajny indywidualizm, nieumiejętność działania w zespole, odcięcie się od wszystkiego i wszystkich. Liderzy nowej partii nie liczą się też z tym obiektywnym faktem, że w 9,5 milionowym kraju trudno uzyskać poparcie milionów takich ludzi, którzy wcześniej byli „nietknięci przez wszystkie poprzednie ekipy polityczne”, bo taki cel sobie postawili, podobnie jak inna nowa partia, do której jeszcze powrócimy. W obliczu głębokiego podziału społeczeństwa liczba takich potencjalnych wyborców jest bardzo niska.

Ponadto społeczeństwo węgierskie nadal myśli tylko w kategoriach prawica lewica. Wyniki sondażu przeprowadzonego przy pomocy Internetu oraz sms-ów przez stację telewizyjną ATV dowodzą, że preferencje wyborcze Węgrów w ogóle nie są zależne od programów wyborczych poszczególnych partii. Programy te są w dużej mierze nieznane, a zwłaszcza są nieczytane przez wyborców, mimo że są one dostępne na stronach internetowych. Znamienne, że w okresie ostatniej kampanii wyborczej Fidesz oficjalnie nie ogłosił żadnego programu. Dlatego też nie można go później oskarżać o niezrealizowanie obietnic wyborczych. Podczas tej kampanii, która, jak wiadomo, zakończyła się ponownym zwycięstwem Fideszu, Orbán powtarzał jeden tylko efektowny slogan: „kontynuujemy”.

Do chwili wycofania kandydatury Budapesztu promocja o cechach propagandy na rzecz igrzysk działała pełną parą. Większość stacji telewizyjnych kilkanaście razy dziennie transmitowała te same reklamy. Na bilbordach co krok uśmiechali się do przechodniów czołowi sportowcy węgierscy apelujący do ludzi o zaangażowanie w sprawę olimpiady. Rząd, który ukrywał wysokość kwoty przeznaczonej na reklamy, pozyskał sporo wybitnych sportowców, by przekonywali społeczeństwo o tym, jak wiele znaczy dla ich sukcesu obecność kibiców-rodaków, zaś dla rozwoju gospodarczego kraju zorganizowanie przez Budapeszt igrzysk. Trudno zresztą oczekiwać od sportowców, by wypowiadali się przeciwko Olimpiadzie, choć niektórzy odmówili wykorzystania ich wizerunku w celach reklamowych. Telewizja transmitowała także wizualizacje miejsc igrzysk. Są to miejsca typowo „narodowe” i najbardziej lubiane przez Węgrów, jak plac za Parlamentem, plac Bohaterów i okolice Zamku „Vajdahunyad” przy obecnym sztucznym lodowisku. Najmniej skuteczna okazała się propaganda prognozująca wielkie wpływy finansowe dla kraju dzięki zorganizowaniu na Węgrzech Olimpiady. Społeczeństwo jest świadome niezadowolenia mieszkańców Rio podczas ostatnich Igrzysk oraz wybuchu kryzysu gospodarczego w Grecji po zorganizowaniu Igrzysk w 2004 r. Znane są także zdjęcia niewykorzystywanych obecnie hoteli i obiektów sportowych 
wybudowanych z okazji najdroższych dotąd XXII Zimowych Igrzysk Olimpijskich zorganizowanych w Soczi w 2014 r.

Tymczasem innej nowej opozycyjnej partii o nazwie „Partia psa z Dwoma Ogonami”"11 $\mathrm{z}$ darów udało się zebrać środki na intensywną antykampanię. Obraz zdezelowanego pociągu budapeszteńskiego metra stanowił niemalże stały element umieszczonych w wielu miejscach stolicy plakatów. Znicz olimpijski wieziony przez metro to aluzja do częstych awarii, w tym także drobnych pożarów. Bilbordy swą niebieską kolorystyką przypominają wcześniejszą kampanię rządową skierowaną przeciwko imigrantom.

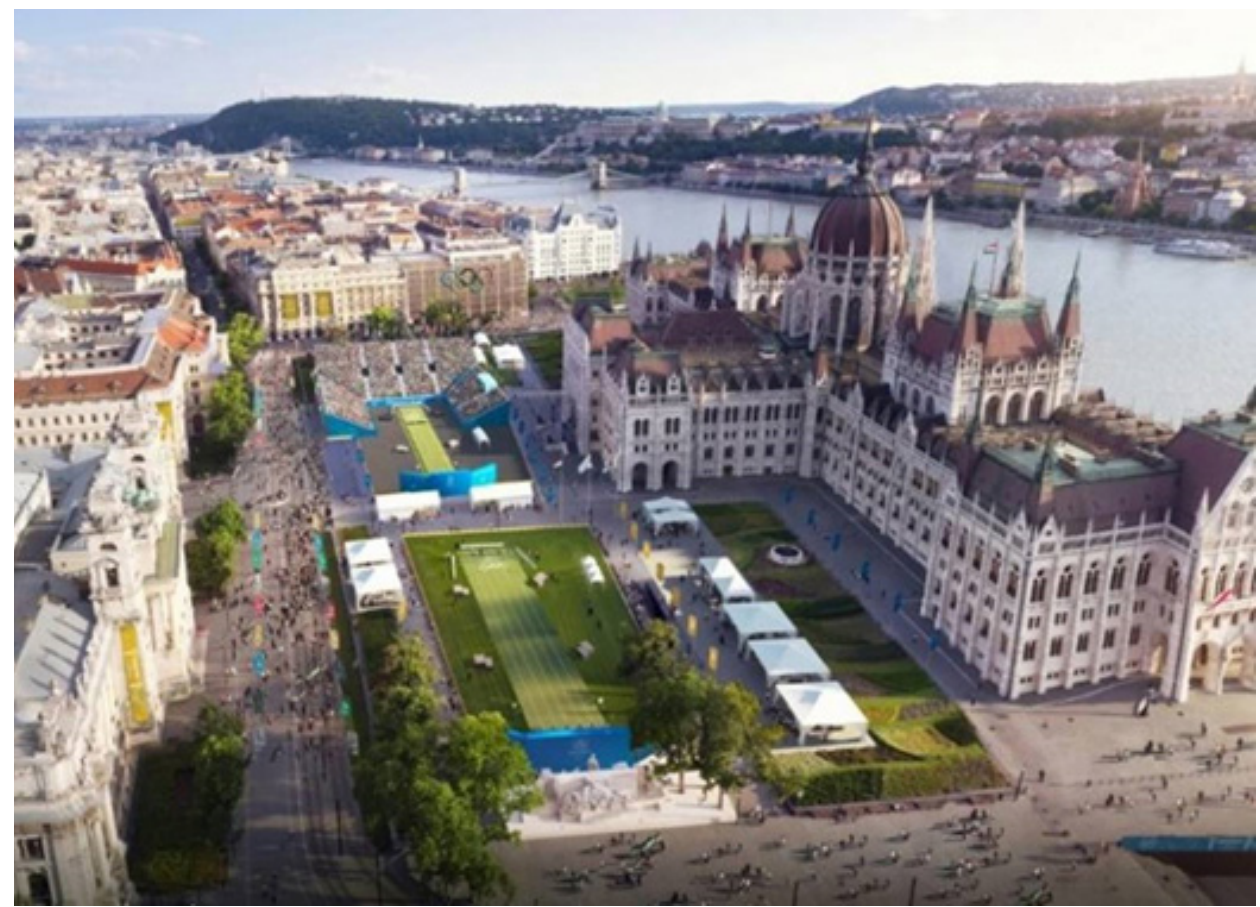

${ }^{11}$ Powstanie i spora popularność tej nowej partii również potwierdza głębokie rozczarowanie Węgrów dotychczasowymi rządami. Jest to typowa „partia żartów”, która w krzywym zwierciadle pokazuje stan psychiczny społeczeństwa. W jej obietnicach wyborczych występuje m.in. wprowadzenie na Węgrzech dla wszystkich wiecznego życia plus dwudziestu lat. W razie wygrania przez nią przyszłych wyborów także piwo ma być bezpłatne i miasto Segedyn ma otrzymać górę, by nie miało kompleksów wobec Budapesztu (przez Segedyn przepływa wprawdzie Cisa, ale miasto oczywiście znajduje się na nizinie). 

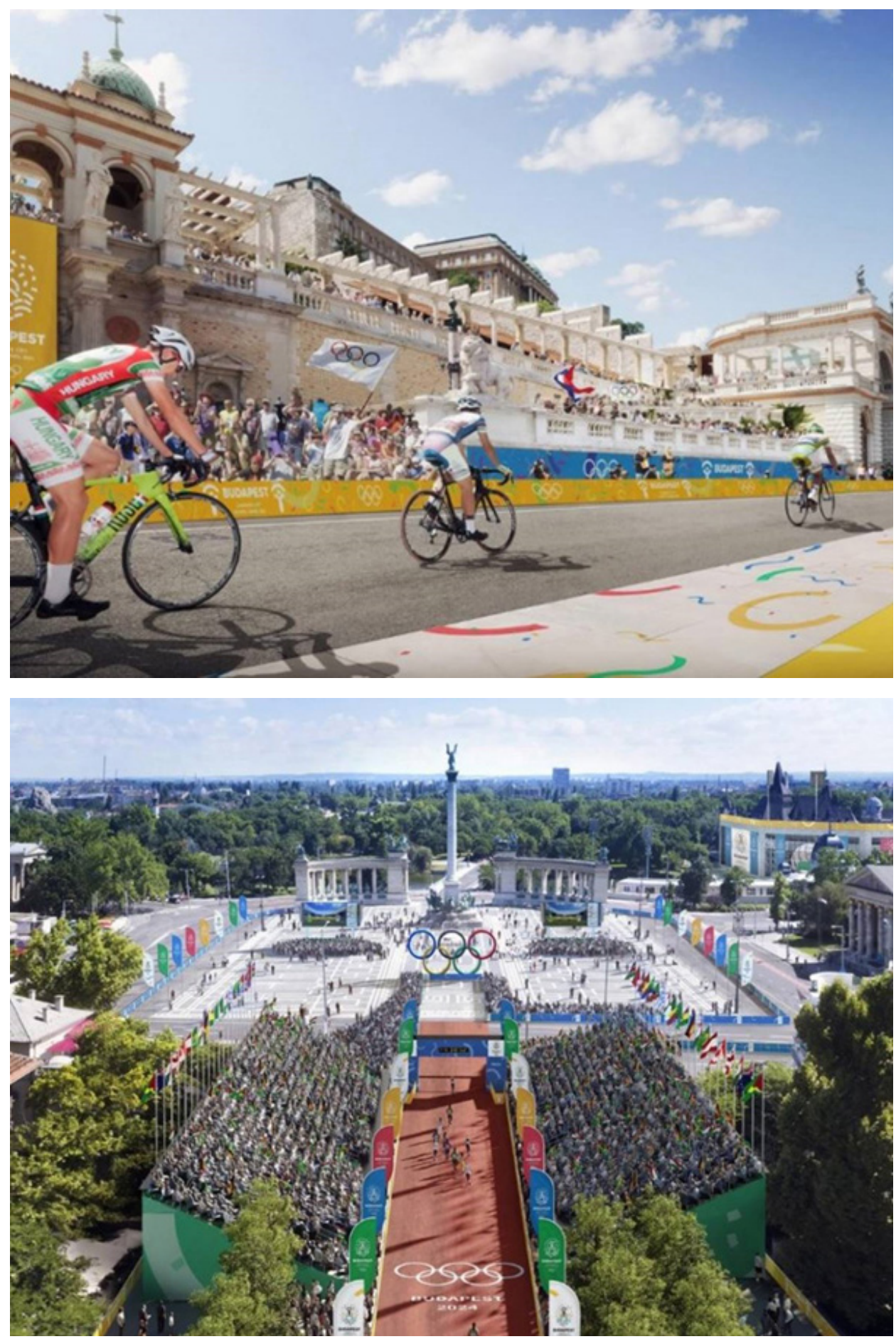


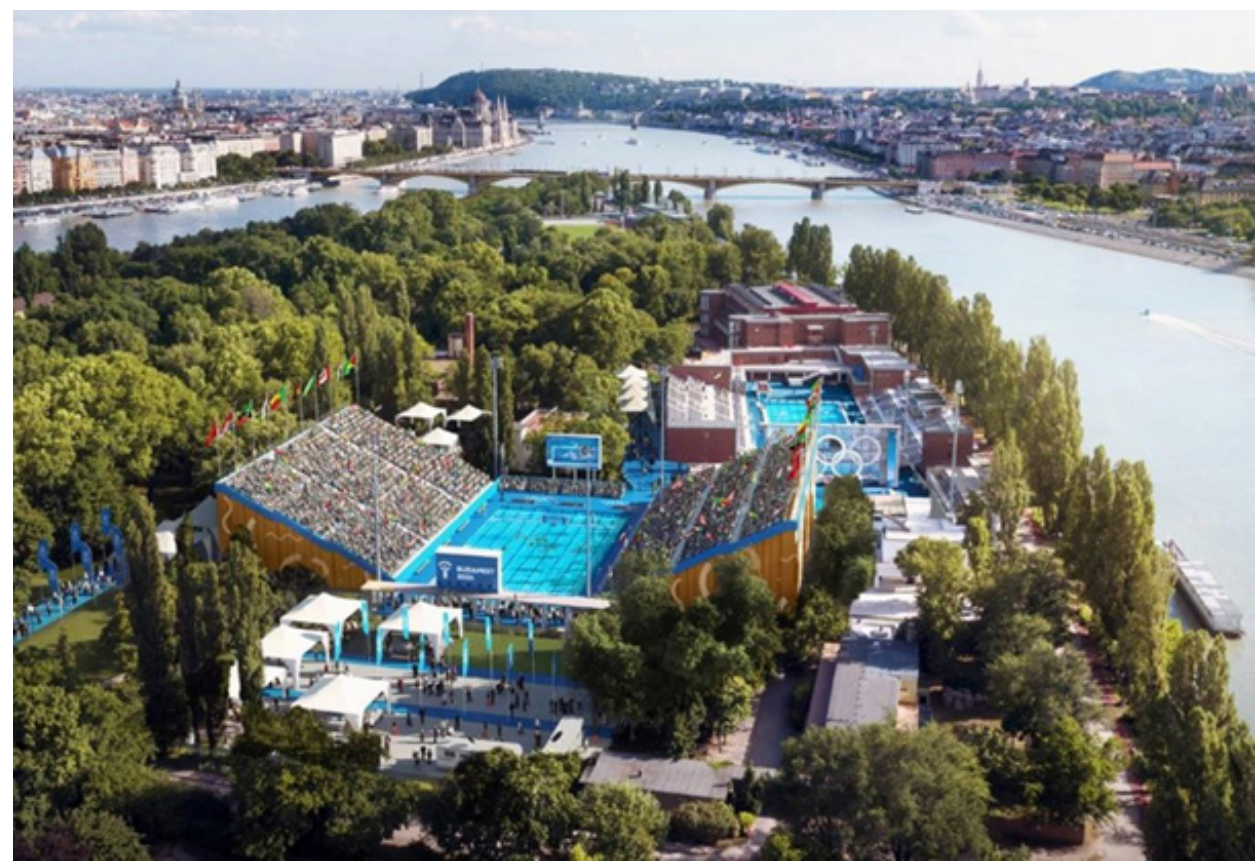

Ilustracja 5,6,7,8. Wizualizacje Olimpiady 2024 r. 01-04.

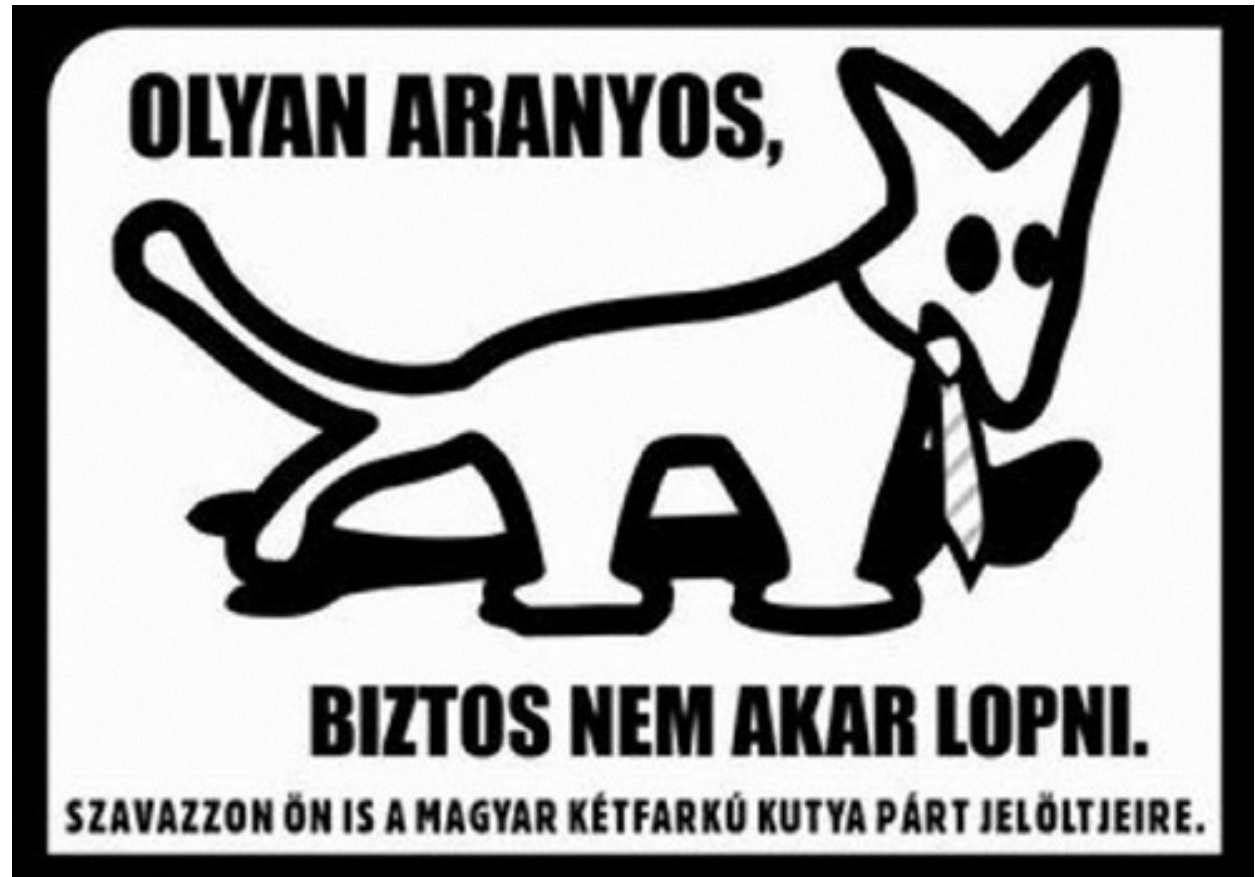



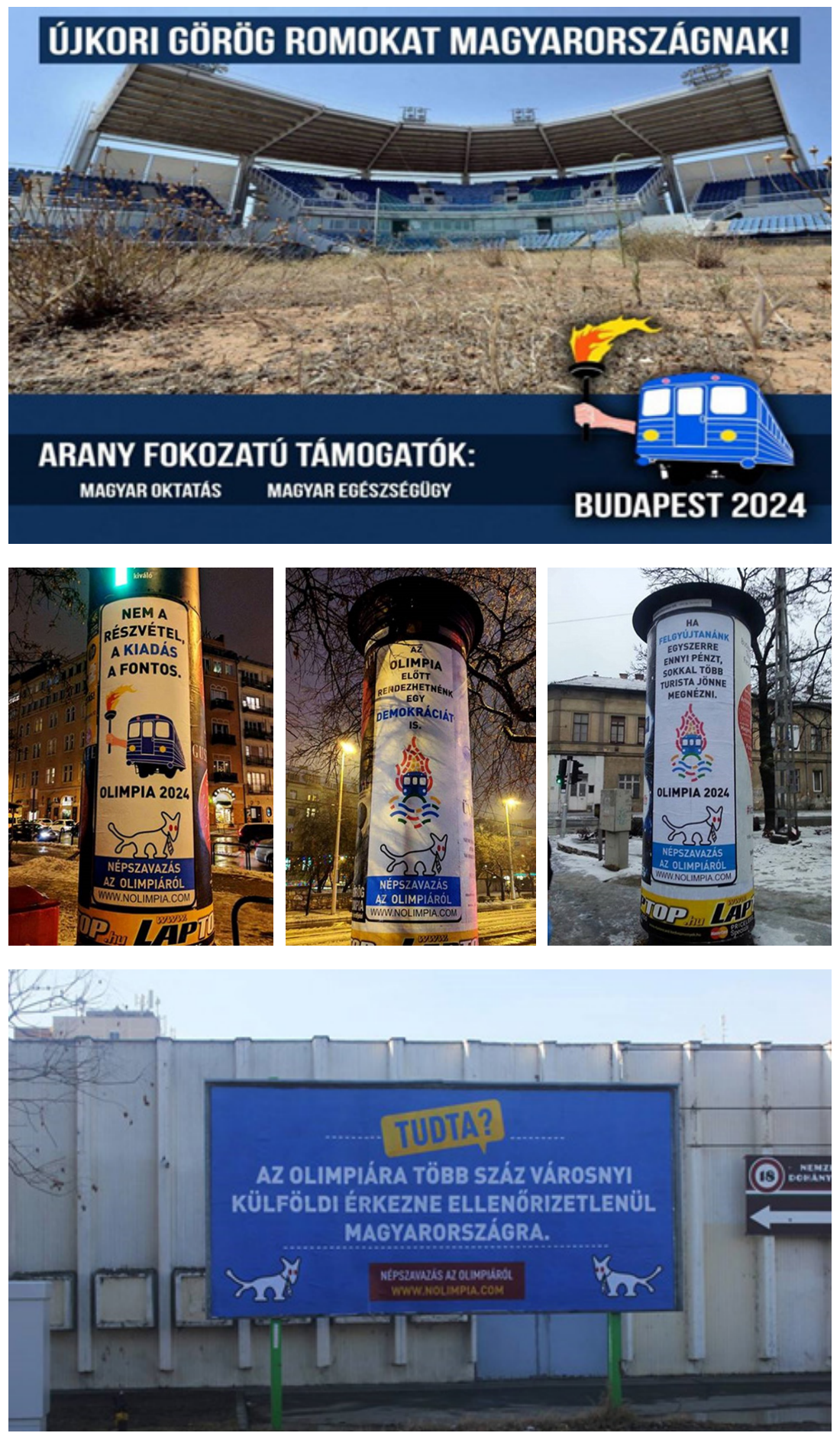


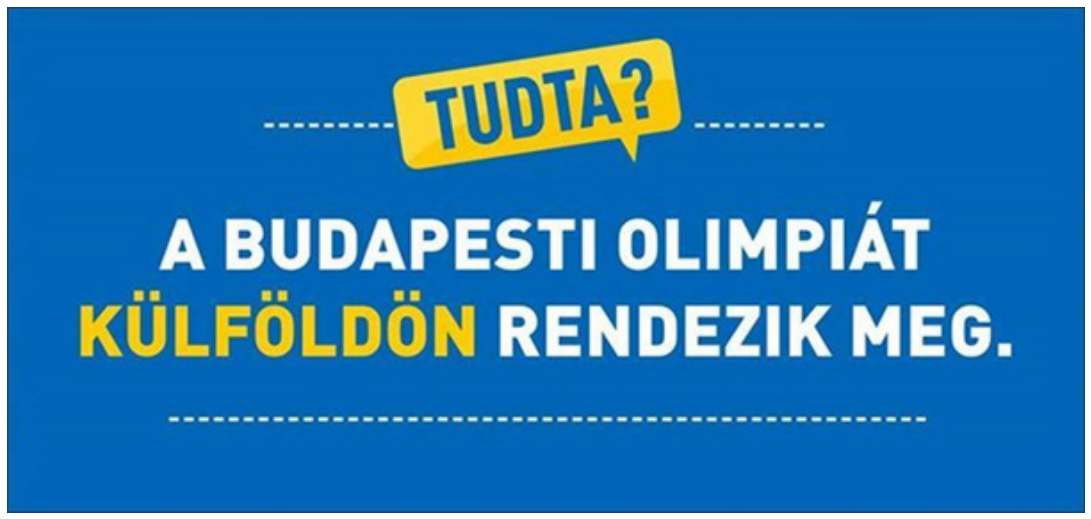

Ilustracja 9. Logo Partii Psa z Dwoma Ogonami i Antykampania 01-06

Napisy na plakatach:

- 01: Żądamy dla Węgier nowożytnych ruin greckich. Sponsorzy ze złotymi medalami: Węgierskie Szkolnictwo i Służba Zdrowia

- 02: Nie uczestnictwo jest ważne, tylko wydatek

- 03: Przed Olimpiadą można by zorganizować demokrację

- 04: Gdybyśmy na raz podpalili tyle pieniędzy, przyjechałoby jeszcze więcej turystów.

- 05: Czy Pan / Pani wiedział(a)? Na Olimpiadę w sposób niekontrolowany przyjechałoby tylu cudzoziemców, ilu ludzi mieszka w kilkuset miastach

- 06: Czy Pan / Pani wiedział(a)? Olimpiada w Budapeszcie zostanie zorganizowana zagranicą

Po rezygnacji przez rząd $\mathrm{z}$ kandydowania w pierwszej kolejności zniknęły z ekranów telewizyjnych oraz z ulic znane twarze sportowców wykorzystane do promocji Igrzysk. Premier i politycy z jego otoczenia wygłaszali przemówienia w ponurym tonie. Orbán mówił o „zabójcach” marzeń, András Bencsik „o zdradzie ojczyzny dokonanej przez 266 tys. budapeszteńczyków”. Niektóre wcześniejsze wizualizacje pojawiły się z innym napisem, np. „Wedle olimpijczyków cały projekt Olimpiady dostał strzał w plecy" - po węgiersku w kark, tj. w tył głowy. Pomimo takiej „oszczędności” dla wielu ludzi stało się jasne, że te same obrazy, plakaty i bilbordy mogą być wykorzystywane dla zupełnie innych celów. Należy tylko zmienić napis i promocja Olimpiady zamienia w potępienie „zdrajców narodu”.

Na nowo zaczęli wypowiadać się także niektórzy olimpijczycy. Tym razem były to wypowiedzi dłuższe, częściowo powtarzające i reinterpretujące słowa premiera, odwołujące się do utraconych marzeń i do zniszczenia jedności narodu. W słowach znanego, wybitnego pięściarza Istvána Kovácsa (jego popularne imię to Kokó) marzenia narodu o Olimpiadzie zostały sprowadzone do wspólnego mianownika z marzeniami o szczęśliwym kraju i narodzie. Walka sportowców o zwycięstwo porównana została do walki o wolność z bronią w ręku. Nawet $\mathrm{w}$ takich, kilkuzdaniowych wypowiedziach widać świadome odwoływanie się do żyjącego w świadomości zbiorowej mitu walczącego bohatera i do mitu bohaterskiej klęski, która ma wyższą wartość moralną niż uciekanie przed trudnościami (tu: finansowymi). W pewnym sensie jest to krzywe zwierciadło i trawestacja idei 


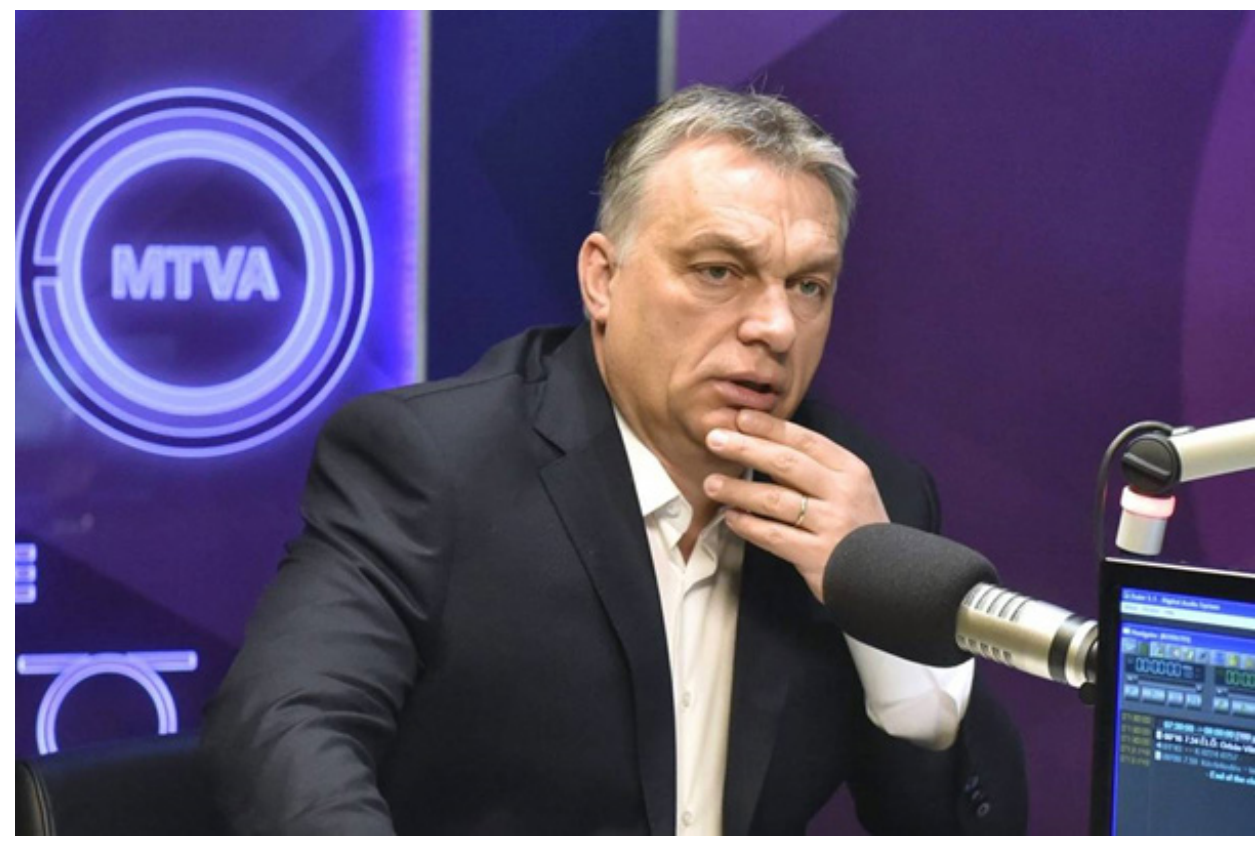

Ilustracja 10. Premier Viktor Orbán ogłasza w radiu wycofanie kandydatury Węgier na organizatora Olimpiady 2024 r. i mówi o „zabójcach marzeń”.

romantycznych podanych w szacie nieartystycznej, znowu przypominającej retorykę nowomowy z lat realnego socjalizmu. W słowach tego zawodnika połączone zostały osobiste dążenia wybitnego sportowca i całego narodu. Z punktu widzenia retoryki propagandowej nie sposób odmówić skuteczności w budzeniu emocji, nie ma bowiem obiektywnych argumentów do zanegowania istnienia w świadomości zbiorowej tak zwanych „wspólnych marzeń o szczęśliwym kraju”:

Sok álmom volt, amit sikerült megvalósitanom. Volt egy közös álmunk, Olimpiát Budapesten. Volt egy közös álmunk, boldog és élhetö országot, nemzetet teremteni. A kettö segithette volna egymást. Ennek most már vége, de nem csak egy-két álommal lett kevesebb, ez sokkal több volt annál... buktunk volna el a harc mezején, még az is erösitett volna minket. Nem hiszem, hogy most bárki is örülne, mert ezzel nem lett jobb, söt. Magyarország, bocsáss meg...12

Miałem sporo marzeń, które udało mi się zrealizować. Mieliśmy wspólne marzenie o Olimpiadzie w Budapeszcie. Mieliśmy wspólne marzenie o szczęśliwym narodzie $i$ kraju, w którym da się żyć. Te dwa czynniki wspieratyby się nawzajem. To już koniec i straciliśmy nie tylko jedno czy dwa marzenia, lecz dużo więcej... lepiej byłoby polec

${ }^{12}$ Zob: http://24.hu/sport/2017/02/23/olimpikonok-a-visszalepesrol-tarkon-lottek-az-egeszprojektet/ Link dostępny 14 marca $2017 \mathrm{r}$. 
na polu walki, i to by nas wzmocniło. Nie wierzę, że teraz ktokolwiek może się cieszyć, bo nie jest lepiej, wręcz przeciwnie. Węry, wybaczcie...

Inna zawodniczka, dwukrotna zwyciężczyni w pływaniu na Igrzyskach Paraolimpijskich, Dóra Pásztory użyła równie mocnych słów. Jej wypowiedź zaczyna się powtarzającym się pytaniem retorycznym „kto mógłby powiedzieć?” - ile osób faktycznie byłoby za i przeciw (tj. w niedoszłym referendum nawet $\mathrm{z}$ tych 266 tys., którzy złożyli podpisy), jaki wpływ wywarłaby na decyzję Międzynarodowego Komitetu Olimpijskiego przewaga głosów na „tak”, itd. W dalszym ciągu zawodniczka mówi o „najgorszym scenariuszu”, o utraconych dwóch latach kandydowania. Nowym elementem tej wypowiedzi jest przywoływanie ulubionego zwrotu z ostatnich lat, będącym już nawet skrzydlatym słowem, o „ciężko pracującym małym człowieku”, którego „uczciwie zarobione pieniądze oraz wiara zostały zmarnowane” na bezsensowną kampanię na rzecz zorganizowania olimpiady.

Sumując, w ostatnich latach sport i ruch olimpijski jest wykorzystywany na Węgrzech w celach propagandowych w sposób porównywalny do okresów i systemów totalitarnych. W propagandzie niekiedy uczestniczą znani sportowcy, którzy czerpią korzyści finansowe ze zwiększonych nakładów na sport. Podczas udzielania się $\mathrm{w}$ tej grze w pewnym sensie stają się oni winnymi. Albo w oczach tej części społeczeństwa, która pieniądze publiczne wolałaby wydać np. na służbę zdrowia, oświatę i stworzenie nowych miejsc pracy, albo w oczach władzy, jeśli odmówią wzięcia udziału w tej propagandzie. Stając przed wyborem, sporo sportowców wybiera to pierwsze, jawnie deklarując wierność partii rządzącej. Chcą oni czy nie, w pewnym sensie ulegają presji politycznej.

Dla scharakteryzowania istniejącego obecnie na Węgrzech sytemu politycznego dumnie nazywanego przez premiera „nowym modelem nieliberalnej demokracji” (po węgiersku ,illiberális demokrácia”) ostatnio coraz częściej używany jest przez opozycję nowy termin: „demokratura”. Skomplikowane wydarzenia związane z kandydaturą Węgier na organizatora Igrzysk w Budapeszcie poświadczają pojawienie się pewnych pęknięć w murze „Systemu Współpracy Narodowej”. Zakwestionowana została bowiem idea olimpiady jako zadania priorytetowego i ogólnonarodowego, za które warto zapłacić każdą cenę.

$\mathrm{Z}$ drugiej strony zreferowane tu wydarzenia w pewnym sensie powstały niespodziewanie i w sposób irracjonalny. Irracjonalny, ponieważ kolejne tomy książki pt. Magyar polip (po polsku „Węgierska ośmiornica”, 2013), Magyar polip 2 (2014), Magyar polip 3 (2015) znanego socjologa, byłego ministra oświaty za czasów rządu socjalistów, w sposób naukowy demaskujące działanie węgierskiego „państwa mafijnego” i systemowość odgórnie sterowanej korupcji, nie spowodowały takiego powszechnego poruszenia i niezadowolenia, jak akurat sprawa zorganizowania Olimpiady. Nie przyczyniły się też do zmniejszenia poparcia dla Fideszu. Należy podkreślić, że książki Bálinta Magyara (tak się nazywa autor) zwracają uwagę na dużo większe problemy systemowe, niż jakimi są rze- 
czywiste i potencjalne nadużycia finansowe dotyczące samej olimpiady i sportu wyczynowego.

Po wydaniu książek Magyara w innym kraju zapewne powstałyby jakieś konsekwencje. Albo dla rządu, albo dla autora - jeśli jego stwierdzenia nie odpowiadają prawdzie. Znaczna część społeczeństwa węgierskiego jednak póki co wszystko wybacza Fideszowi, bo wedle niej jedynie partia rządząca, a w szczególności osobiście premier potrafi prowadzić skuteczną ,walkę z Brukselą" i potrafi reprezentować wobec Europy „narodowy interes Węgrów”.

„Interes Węgrów” - i wszystko co węgierskie bądź narodowe ${ }^{13}$ - to święte hasło w kraju, w którym przez setki lat na darmo walczono o wolność i niepodległość. W świadomości zbiorowej zakompleksionego narodu nadal żywo istnieje nawet pojęcie „Boga Węgrów” spopularyzowane w okresie Wiosny Ludów przez wieszcza narodowego Sándora Petöfiego". ${ }^{14}$

Odrębność języka ugrofińskiego w centralnej części Europy nadal skutecznie potwierdza przeświadczenie Węgrów o ich wyjątkowości. Taka idea również popularyzowana jest także przez oficjalną politykę. Publiczne występy i przemówienia premiera bardzo często zaczynają się słowami „my, Węgrzy”, by w dalszym ciągu podkreślić różnice dzielące naród węgierski od wszystkich pozostałych. W dodatku hermetyczność języka węgierskiego zapobiega także temu, by bliżsi i dalsi sąsiedzi od razu i bezpośrednio mogli zareagować na objawy werbalnej propagandy. Skrajna prawica na czele z partią , Jobbik” skutecznie promuje seklersko-węgierskie pismo ryte, którego wczesna wersja używana była w dobie zajmowania ojczyzny. Obecnie, w epoce komputerowej, stanowi ono wprawdzie parodię, ale też poświadcza „wyjątkowość" Węgrów - chociażby przez skuteczne i celowe połączenie tradycji pogańskich i chrześcijańskich. ${ }^{15}$. Są to sprawy niby dalekie od sportu, ale bez ich znajomości trudno zrozumieć na pierwszy rzut oka mało logiczne wydarzenia nawet w dziedzinie sportu i współczesnego życia kulturalnego na Węgrzech.

${ }^{13}$ Po 2010 r. powstały na Węgrzech „,narodowe sklepy tytoniowe”, które obecnie mają wyłączność w sprzedaży wyrobów tytoniowych. Utworzony został „narodowy system płatności mobilnych" i „narodowy system płatności” za używanie „narodowej sieci dróg”. Rząd nazywa siebie „rządem narodowym”, a swoich zwolenników „ludźmi o uczuciach narodowych”. Przymiotnik ten - podobnie jak przymiotnik 'węgierski' - ma coraz bardziej wąskie znaczenie i specyficzną, nową konotację.

${ }_{14}$ Pojęcie to występuje w najbardziej znanym i popularnym wierszu patriotycznym Petőfiego, w Nemzeti dal (Pieśni narodowej), recytowanym po raz pierwszy przez poetę na schodach Muzeum Narodowego 15 marca 1848 r. (W dniu wybuchu powstania węgierskiego). Mimo że wiersz może być znany wielu Polakom dzięki przekładowi artystycznemu dokonanemu przez Juliana Wołoszynowskiego, w polskiej wersji akurat nie występuje „Bóg Węgrów”. Powtarzający się w końcu każdej zwrotki refren „A magyarok Istenére/Esküszünk,/Esküszünk, hogy rabok tovább/Nem leszünk” (w przekładzie filologicznym: Przysięgamy na Boga Węgrów, że dalej nie będziemy niewolnikami) w polskim przekładzie artystycznym brzmi następująco: „- Przysięgamy! Ty nad nami,/Boże sam! /Nigdy już niewolnikami/Nie być nam!”.

${ }^{15}$ Nawet w Węgierskiej Bibliotece Cyfrowej (MEK) setki węgierskich utworów literackich udostępnia się w piśmie rytym. 


\section{Streszczenie}

Od r. 2010 rząd węgierski ważną rolę przywiązuje do sportu, w tym do piłki nożnej i promocji ruchu olimpijskiego. Mimo braku odpowiedniej infrastruktury w szkołach węgierskich wprowadzono codzienne lekcje wychowania fizycznego. Wszędzie w kraju realizowane są wielkie inwestycje sportowe. Wśród nich priorytetowe miejsce przypada budowie i rekonstrukcji stadionów. Między innymi we wsi rodzinnej premiera wybudowany został stadion, który potrafi zmieścić 3.500 kibiców, podczas gdy liczba mieszkańców Felcsút wynosi mniej niż 2000 osób. Wyniki sportu wyczynowego wykorzystywane są przez politykę w sposób porównywalny do metod stosowanych w XX-wiecznych systemach totalitarnych. Podczas XXXI Letnich Igrzysk Olimpijskich za ogromne koszty wybudowany został w Rio „Dom Węgierski”, który miał promować Budapeszt przy ubieganiu się o prawo do organizowania Igrzysk w $2024 \mathrm{r}$. Z powodu inicjatywy pewnej organizacji obywatelskiej ws. rozpisania referendum na początku 2017 r. kandydatura została wycofana. Opór opozycyjnych polityków i pewnej części społeczeństwa do olimpiady wynikał z rosnącej korupcji, która dosięga już najwyższych władz politycznych.

Słowa kluczowe: propaganda, sport, Węgry, Letnie Igrzyska Olimpijskie, Fidesz.

\section{THE EXPLOITATION OF OLYMPIC GAMES IN THE MEDIA FOR STRENGTHENING THE NATIONAL IDENTITY OF HUNGARIANS}

\section{Su m mary}

Since 2010 the Hungarian government has played a major political role in the development of sports, including football and the Olympic movement. Despite the lack of proper infrastructure, daily physical education classes were introduced in Hungarian schools. Across the country, significant sports projects are being realised. Among these, the building and reconstruction of stadiums are a priority. In the home village of the Hungarian Prime Minister, a stadium capable of accommodating 3500 spectators was also built, while the number of inhabitants of Felcsút is below 2000.The results of competitive sports are utilised for enhancing national pride and the achievements of the government in a way similar to the methods of the totalitarian political regime of the 20th century. During the 2016 Summer Olympics in Rio de Janerio, a Hungarian House was built, which was designed to popularise and support Hungary's tender for organising the 2024 Olympic Games. Owing to a civil movement's initiative to hold a referendum on the issue, the government withdrew the application at the beginning of 2017. The resistance to the Olympics on behalf opposition parties and partly of society was primarily caused by the growing corruption reaching the highest levels of political leadership.

Keywords: propaganda, sport, Hungary, Summer Olympic Games, Fidesz. 